\title{
Investigating the Effect of Cooperative Learning and Competitive Learning Strategies on the English Vocabulary Development of Iranian Intermediate EFL Learners
}

\author{
Neda Fekri ${ }^{1}$ \\ ${ }^{1}$ Department of English language, Aliabad Katoul Branch, Islamic Azad University, Aliabad Katoul, Iran \\ Correspondence: Neda Fekri, Department of English language, Aliabad Katoul Branch, Islamic Azad University, \\ Aliabad Katoul, Iran.
}

Received: September 10, 2016

Accepted: September 26, 2016

Online Published: September 27, 2016

doi: 10.5539/elt.v9n11p6

URL: http://dx.doi.org/10.5539/elt.v9n11p6

\begin{abstract}
The current study investigated the effect of cooperative and competitive learning strategies on the acquisition of English vocabulary development by Iranian EFL intermediate learners. In addition, it explored what type of theses strategies was more effective. In such doing, utilizing an Oxford Placement Test (OPT), 45 out of 77 Iranian EFL intermediate learners from four language institutes in Tehran, Iran, were randomly selected. Then, the selected participants were equally divided into three groups, i.e. a control group and two experimental groups, $(\mathrm{N}=15)$. On experimental group was taught via cooperative learning, and the other experimental group was taught via competitive learning. The obtained results were analyzed via one-way ANOVA and independent sample t-test. The results revealed that both of these strategies were effective in English vocabulary development by Iranian EFL intermediate students. Furthermore, the findings indicated that the performance of the experimental group via cooperative strategy was better than their counterpart in the experimental group whom was taught via competitive strategy.
\end{abstract}

Keywords: cooperative learning, competitive learning, English vocabulary development

\section{Introduction}

The teaching in the EFL classroom is typically based on competitive learning. The teacher in EFL classroom allocates a lot of time to identify curriculum in the class. At that time, students should listen to the lecture thoughtfully and inactively. Therefore, they force to utilize textbook to memorize English grammar rules and translation skills (Wang, 2007). The teacher attempts to help students to get good grades in English, uses a traditional instructional method like competitive learning (Wang, 2007). According to Brown (1994), a traditional instructional method makes competitive learning and causes individual performance in the classroom teaching. Therefore, competitive learning also has many impacts on teaching. It seems that cooperative learning is a potential solution to teach problems (Ellis, 2008). In fact, cooperative learning is a method of teaching, inspires social skills through students' interaction, and to enhance the language learning.

Cooperative learning offers opportunities for learners to develop effective learning. Furthermore, it offers opportunities for learners to practice English and to learn more successfully from classmates and teachers. Moreover, it helps social relations among students through interaction in group members (Lai, 2002; Wei \& Chen, 1993). Many researchers investigated the best ways to teach English language. They studied the balance between cooperative learning and competitive learning. Additionally, cooperative learning advocates attraction heavily on theoretical effort of developmental psychologists Jean Piaget and Lev Vygotsky, both of whom stressed the central role of social interaction in learning.

Lev Semeonovich Vygotsky, a Russian psychologist introduced the concept of the Zone of Proximal Development (ZPD) during the last two years of his short life in the 1934. Vygotsky suggested a large number of meanings of the Zone of Proximal Development. On the other hand, one of the most well-known definitions is "the distance between the actual developing levels as defined by independent problem solving and the level of potential development as defined through problem solving under adult assistance, or in cooperation with more skilled peers". Actually, it is "the different between what a learner can do without help and what he or she can do with help" (Vygotsky, 1987, p. 112). Such concept of the ZPD caused many researchers concentrated on 
interaction itself establishes the learning process, which is typically social rather than individual in nature (Hatch, 1987). Additionally, Lev Vygotsky was given additional motivation in the 1990 to the field of second language learning, this viewpoint of thinking and research, here named 'socio-cultural' theory. The origin of this theory is from constructivism. Hashimoto and Nyikes (1997) state that Piaget and Vygotsky can be both termed as constructivists; however, they follow two different perspectives.

The traditional education methodology is generally based on students learning independently and highlights the reciprocal effect between students and teachers, in addition to students and textbooks. On the other hand, by developing new education pedagogy containing the application of some new education theories such as learning by discovery, solving problems together, more argument in class, etc., cooperative learning education theory is considering the reciprocal effect among students. Cooperative Learning is a kind of education methodology that highlights the mutual result and cooperation between students. Millis and Cottell (1998) have considered CL technique which de-emphasizes competition and as an alternative which inspires students to work together and to be successful as a team. Students to become successful must cooperate and encourages enjoyment of others doing well. CL had positive effect on both teachers and students. Their learning output may improve because they must also teach their colleagues; thereby improving their knowledge of the material, and this is the case for the other learners who hear the information in peer language.

\subsection{Statement of the Problem}

Many researchers have examined the influence of different techniques of cooperative and competitive learning on different constituents of the English language. Some researchers have compared cooperative learning to competitive learning strategies in various aspects of language learning, for example, complications between cooperative learning and traditional learning method. However, no researcher has examined the influence of cooperation learning and competitive learning strategy on the acquisition of English lexicons. Consequently, the aim of the current study was to explore the influence of cooperative and competitive learning strategy on English vocabulary development by Iranian EFL intermediate students. It has been proven that all students can take benefit from the cooperative learning, including English language learners, academically gifted and mainstream students. Since cooperative learning can enhance the learning it also promotes respect and friendships among various groups of students. Actually, the more variety in a team, the higher the profits for each learner. In fact, in order to perform a variety of learning tasks, peers learn to rely on each other positively (Long, 1996).

In addition, the role of teacher in the competitive learning strategy is important, when he only asks students to repeat especially in traditional methods. There is not any cooperation in the class among peer students in such methods. Students are inspired to find roles when they are taught in the group forms. The other weakness of the traditional method is the absence of creativity among students, and dependence on their teacher. It is difficult for them to solve the problem in a situation of learning without teacher's assistance since the method is based on the teacher.

In Iran, the most of teachers are likely to use the teacher-centered method. After finishing English study in the language institution or school, most students forget what to be learned, because they depend on their teachers. The best solution is the student-centered method as they can study and learn by themselves. The student-centered method is a cooperative learning strategy. Therefore, students are responsible for each other's learning. Furthermore, they are encouraged to think based on 'positive interdependence', as they are thinking cooperatively in group. Thus, the language acquisition is simplified, when students interact in the target language. According to Richards and Rodgers (2001), "cooperative learning strategy increases the motivation, reduces the stress, and also creates a positive affecting classroom climate." (p. 13). Accordingly, the current study investigated whether teaching based on cooperative and competitive learning could improve student's learning of English vocabulary development.

\subsection{Research Questions}

Based on the above mentioned purpose of the study, the present study was an attempt to answer the following questions and hypotheses:

$\mathrm{RQ}_{1}$. Is there any significance difference between the effects of cooperative and competitive learning strategies on Iranian EFL intermediate learner's acquisition of English vocabulary development?

$\mathrm{RQ}_{2}$. What type of strategies (cooperative \& competitive) is more effective on Iranian EFL intermediate learner's English vocabulary development?

\subsection{Research Hypotheses}

$\mathrm{HO}_{1}$. There is no significant difference between the effect of cooperative and competitive learning strategies on 
Iranian EFL intermediate learners' acquisition of the English vocabulary development.

$\mathrm{HO}_{2}$. Cooperative and competitive strategies have the same effect on Iranian EFL intermediate learner's acquisition of the English vocabulary development.

\subsection{Review of the Literature}

Concerning the impact of competitive and cooperative learning on English language proficiency, in this section some studies conducted on these types of learning are discussed.

Jacobs et al. (1996) discovered that L2 learners had more language exercise opportunities and presented a wider extent of language functions in team or pair work than in teacher-fronted classes. They concluded that CL suggested opportunities for pre-adjusted input that emphases on meaning in lower-anxiety contexts internationally modified input, and comprehensible output. In a follow-up study, Jacobs (1988) has compared CL with traditional methods and found that:

1). enhances the measure of language students use,

2). increases the quality of the language students use,

3). Balances the learning opportunities for all of them

4). Produce a less threatening learning climate for language use.

In addition, Pattanpichet (2011) examined the effects of using CL in encouraging students' speaking success. 35 undergraduate students joined the study. She came to the conclusion that cooperative learning had a positive effect of the oral ability of the learners. In another study, Woolfolk and Suwantarathip (2010) explored the influence of cooperative learning approach in language ability and studied its effectiveness in decreasing foreign language anxiety. The results showed that using the cooperative learning as part of the language learning led to decreasing the students' anxiety and increasing the language proficiency. The researchers believed that the reason of decreasing the students' anxiety was probably because of opportunities this learning environment provided for them to support, inspire, and praise each other. Therefore, students were relaxed in such a learning environment and developed their language proficiency. In a more recent study, Talebi and Sobhani (2012) investigated the impact of CL on speaking proficiency of English language learners. Sample of experiment included 40 male and female students enrolled in a speaking course at an IELTS Center in Iran. For collecting the data, an oral interview was performed. Instructions in speaking three terms per week were given to the control group for one month, whereas the experimental group was trained speaking skills through CL. The findings of the study indicated that the function of the experimental group on oral interview held at the end of the course overtook the control group. The mean score of control group was significantly lower than the experimental group.

Finally, Hosseini (2012) explained that although many researches verify the benefit of CL over traditional methods of teaching, very little researches have directly compared the efficiency and value of CTBL and other popular CL methods like LT. Hosseini carried out different research in the last decade. He conducted a comparative experimental study to explore the complex impacts of CTBL with LT of Johnsons, and the traditional chalk-and-talk mode of performance or Traditional Lecture Method (TLM) on Indian and Iranian undergraduate learners. One significant result of his study was more successful of CTBL in increasing the participants' metacognitive and affective strategies. It showed that CTBL, rather than LT, helped more effectively to the development of the participants' retention of information. The study also revealed more comprehensively contribution of CTBL to the success of the worst performers. Hosseini also found that CTBL simplified the development of learning-how-to-learn skills, long-term preservation rather than survival skills, and recognition memory of the participants, and meaningfully improved the quality of knowledge the participants learned.

\section{Methodology}

\subsection{Participants}

Based on the results of an Oxford Placement Test (OPT), 45 out of 77 Iranian EFL intermediate learners from four language institutes in Tehran, Iran, were randomly selected as the main participants of the current study. Their age ranged between 19-22 years old. Then, the selected participants were equally divided into three groups, i.e. a control group and two experimental groups $(\mathrm{N}=15)$. It was assumed that nearly all the participant had a similar foreign language learning experience.

\subsection{Instrumentations}

Three main instruments were utilized in the present study. First, in order to check the level of general language proficiency of the participants at the beginning of the study, and find out a homogenous sample, an Oxford 
Placement Test (OPT) was utilized. Using the KR20 formula, the internal consistency of the test was calculated and reported to be (.78), which was fairly satisfactory. Furthermore, to ensure its validity, it was reviewed by two language experts and their comments were utilized in the follow-up version of the main study. The second instrument was a standard vocabulary pre-test was as the other required instrument in this study. The aim was to determine whether participants were homogeneous in their knowledge of English vocabularies. This pretest consisted of 100 multiple-choice test items for intermediate level. The items of the test were also be reviewed by two experts of the field to ensure the validity. In addition, administering Cronbach Alpha, its reliability was calculated. The third instrument was a vocabulary test as the posttest. This test consisted of 100 multiple-choice questions. The only difference between this test and the pretest was that the sequence of the items.

\subsection{Procedures}

After selecting the participants, they were randomly divided into three groups. In order to be ensuring that the two groups are equally proficient after selecting the groups, a pretest containing 100 questions was administered. Then, the English lexicons, including vocabularies, were taught to the two experimental groups in eight weeks. While English vocabularies were taught to the control group based on the traditional ways of teaching including explicit explanation of rules, doing drills and exercises from the textbook. Prior to the posttest, the researcher ensured that the instructors implement the appropriate strategies, cooperative or competitive, during the treatment. Then, conducting the posttest, the results of the performance of three groups were compared. In addition, the experimental groups' mean scores were analyzed to investigate the most influential strategy on English vocabulary development.

\subsection{Data Analysis}

The statistical analysis used to analyze the quantitative data includes one-way ANOVA to assess the difference among three groups, as well as independent sample t-test to compare the performance of the experimental groups regarding two strategies were conducted to assess differences across the two groups after the instructions.

\section{Results and Discussion}

The results of one-way ANOVA showed that there was a significant difference in how the two experimental groups outperformed on the test compared to their counterpart in the control group, $F(2,29)=49.07, p=$ $0031<.05)$.

Table 1. The one-way ANOVA results

\begin{tabular}{llllll}
\hline Source of Variance & SS & df & MS & F & Sig. \\
\hline Between groups & 477.43 & 2 & 322.43 & & \\
Within groups & 312.07 & 39 & 4.83 & 49.07 & .0031 \\
Total & 688.11 & 59 & & & \\
\hline
\end{tabular}

In order to determine the location of difference when $\mathrm{F}$ value was significant, a post-hoc analysis was also conducted. Based on post-hot tests, we concluded that there were no significant differences between EG via cooperative strategy and EG via competitive strategy, whereas, there was a significant difference between theses experimental groups (two experimental groups) and the CG (the control group). Thus, the answer to the first research question became clear, and the first hypothesis was rejected. However, in order to compare the performance of the experimental groups on the posttest, and answer to the second question and hypothesis, an independent sample t-test was conducted. The result is presented in Table 2. 
Table 2. Independent sample t-test results

\begin{tabular}{|c|c|c|c|c|c|c|c|c|c|}
\hline & $\mathrm{F}$ & Sig. & $\mathrm{t}$ & Df. & $\begin{array}{l}\text { Sig. } \\
\text { (2-tailed) }\end{array}$ & $\begin{array}{l}\text { Mean } \\
\text { Difference }\end{array}$ & $\begin{array}{l}\text { Std. Error } \\
\text { Difference }\end{array}$ & Lower & Upper \\
\hline Equal variances assumed & .156 & 0.599 & -3.658 & 39 & .003 & -1.667 & .456 & -3.695 & -.861 \\
\hline Equal variances not assumed & & & -3.658 & 45.845 & .002 & -1.667 & .456 & -2.584 & -.749 \\
\hline
\end{tabular}

a. Levene's Test for t-test for Equality of Means

b. Equality of Variances $95 \%$ Confidence Interval of the Difference.

According to Table 3. the p-value of ,the Levene's Test for Equal variances was 0.599, which indicated that there was an insignificant difference between the variances of two groups. Therefore, the statistics in the first row should be used. In the first row, the p-value was equal to 0.003 which was lower than 0.05 and revealed that there was a significant difference in lexicon acquisition of English vocabularies between performance of students taught through cooperative and competitive learning instructions. Thus, based on the t-test results, which the experimental group was taught through cooperative learning instruction outperformed the experimental group taught via competitive strategy learning, and thereby the answer to the second question became clear and the second null hypothesis stating was rejected.

\section{Conclusion}

The findings of the present study revealed that both cooperative and competitive learning strategies were influential in English vocabulary development by Iranian EFL intermediate students. In addition, comparing the effectiveness of cooperative and competitive learning strategies, the results of independent sample t-test indicated that the performance of the experimental group via cooperative strategy was better than their counterpart in the experimental group whom was taught via competitive strategy.

The results of the present study are in line with the previous studies by Slavin (1996), Tanner and Marr (1997) who showed that cooperative learning models has a significant effect on students' proficiency. Moreover, the findings of the present study are in agreement with the findings of the study by Chiason, Okwu and Kurumeh (2010) who found a high, level of achievement difference between students taught using cooperative learning strategy and conventional learning strategy. The results of the present study are also in line with the previous studies of Akinbobola (2006) whose study revealed that students taught using the CL method performed better than those taught using the conventional method.

The findings of the current research have several pedagogical implications for instructional and curriculum design development. First, EFL learners should learn to understand the nature and the purpose of CL. Thus, the language instructors should make attempt to enhance their awareness of the advantages of employing various types of CL related methods. In Iranian EFL educational settings that CL is a very important method for learners to be aware of how new language features are utilized in real life contexts and everyday communication.

In Iranian context, successful language learners may be regarded as informants for students experiencing less success in language learning concerning utilizing various features in miscellaneous contexts. In addition, language instructors should be more aware of importance of CL and of that whether the learners are or are not aware of the goals of noticing the various utilizations of the new features in real settings rather than just paying attention to the instructional textbooks. Furthermore, it must be noted here that the development of new language teaching methods to enhance communicative ability in conventional classes should be taken into consideration by material and curriculum designers.

\section{References}

Brown, H. D. (2000). Principles of language learning and teaching. New York: Longman.

Brown, H. D. (2001). Teaching by principles: An interactive approach to Language pedagogy. NY: Addition Welsey Longman.

Berk, L., \&Winsler, A. (1995). Vygotsky: his life and works and Vygotsky approach to development. In scaffolding children's learning: Vygotsky and early childhood learning (p. 24). Natl. Assoc for Educ. Of Young children.

Biesenbach-Lucas, S. (2004). Asynchronous Web discussion in teacher training Courses: promoting. 
Collaborative Learning or not? AACE Journal, 12(2), 155-170.

Celce-Murcia, M., (1991). Teaching English as a second or foreign language. p. 244.

Cohen, E. G. (1994). Designing group work. New York: Teacher's College. http://dx.doi.org/10.1300/J009v17n01_05

Chiu, M. M. (2000). Group Problem Processes: Social interaction and Individual actions. Journal for the theory of Social Behavior, 30(1), 27-50. 600-637. http://dx.doi.org/10.1111/1468-5914.00118

Chiu, M. M. (2004). Adapting teacher interventions to student needs during cooperative learning. American Educational Research Journal, 41, 365-399. http://dx.doi.org/10.3102/00028312041002365

Chiu, M. M. (2008). Flowing toward correct contributions during groups' Mathematics problem solving: A statistical discourse analysis. Journal of the Learning Sciences, 7(3), 415-463. http://dx.doi.org/10.1080/10508400802224830

Craft, R. (1943). Dictionary of language teaching and applied linguistics. New York: Pearson Education.

Davydov, V. (1998). The concept of developmental teaching. Journal of Russian and East European Psychology, 36(4), 11-36. http://dx.doi.org/10.2753/RPO1061-0405360411

Dillenbourg, P. (1999). What do you mean by collaborative learning? In P. Dillenbourg (Ed.), Collaborativelearning: Cognitive and Computational Approaches (pp. 1-19). Oxford: Elsevier.

Deutsh, M. (2000). Cooperation and competition. In M. Deutsh, \& P. T. Coleman (Eds.), The handbook of conflict resolution theory and practice. San Francisco: Jossey-Bus Publisher.

Ellis, R. (2002a). The place of grammar instruction in the second/foreign Language Curriculum. In E. Hinkle, \& S. Fotos (Ed.), New perspective on Grammar teaching in second language classrooms. MahWah, N J: Lawrence Erlbaum.

Ellis, R. (2000). Task-based research and language pedagogy. Language Teaching Research, 4, 193-220. http://dx.doi.org/10.1177/136216880000400302

Freund, L. S. (1990). Material regulation of children's problem solving Behavior and its impact on children's performance. Child development, 61, 113-126. http://dx.doi.org/10.2307/1131052

Gass, S. (1997). Input, interaction, and second language learner. Mahwah, NJ: Lawrence Erlbaum Associates.

Gokhale, A. (1995). Collaborative Learning Enhances Critical Thinking. Journal of Technology Education, 7(1), 22-30. http://dx.doi.org/10.21061/jte.v7i1.a.2

Ghorbandordinejad, F. (2011). Language teaching methodology. Tehran: Zeiton sabz (pp. 127-131).

Kovalainen, M., Kumpulainen, K., \&Vasama, K. (2001). Orchestrating Classroom interaction in a community of inquiry: Modes of teacher participation. Journal of classroom Interaction, 36(2), 17-28.

Lantolf, J. P., \& Thorne, S. L. (2006). Sociocultural theory and the genesis of second language development. Oxford: Oxford University Press.

Larsen-Freeman, D. (1986). Techniques and principles in Teaching (pp. 159-175). Oxford: Oxford University Press.

Mercer, N., \& Fisher, E. (1992). How to teachers help children to learn? An computer-based activities. Learning and Instruction, 2, 339-355. http://dx.doi.org/10.1016/0959-4752(92)90022-E

McDonell, W. (1992). The role of the teacher in the cooperative learning Classroom. In C. Kessler (Ed.), Cooperative Language learning: A teacher's resource book (pp. 163-174). Englewood Cliffs, NJ: Prentice Hall.

Nassaji, H., \& Swain, M. (1997). A Vygotskian perspective on corrective Feedback in L2: The effect of random versus negotiated help on the learning of English articles. Language Awareness, 9(1), 34-51. http://dx.doi.org/10.1080/09658410008667135

Nyikes, M., \& Oxford, R. L. (1997). A factor analytic study of language learning strategy use: interpretations from information Processing Theory \& Social Psychology. Modern Language Journal, 77(1), 11-23. http://dx.doi.org/10.1111/j.1540-4781.1993.tb01940.x

Rezaee, A., \& Azizi, Z. (2012).The role of Zone of Proximal Development. Language Teaching and Research, $3(1), 51-57$. 
Richards, L. A., \& Rodgers, Theodore S. (2001). Approaches and methods in language teaching (2nd ed.). Cambridge: Cambridge University Press. http://dx.doi.org/10.1017/CBO9780511667305

Ross, J., \& Smythe, E. (1995). Differentiating Journal for cooperative Learning to meet the needs of gifted learners: A case for transformational leadership. Journal for the Education of the Gifted, 63-82. http://dx.doi.org/10.1177/016235329501900105

Sternberg, R. J., \& Grigorenko, E. L. (2002). Dynamic testing: The nature and measurement of learning potential. Cambridge: Cambridge University Press.

Valsiner, J. (1998). The guided mind. Cambridge, MA: Harvard University Press.

Van der Veer, R., \&Valsiner, J. (1991). Understanding Vygotsky: A quest for Synthesis. Oxford: Blackwell.

Vygotsky, L. S. (1962). Thought and Language. Cambridge. MA: MIT Press. http://dx.doi.org/10.1037/11193-000

Wang, T. P. (2007). The comparison of difficulties between cooperative learning and traditional teaching methods in college English teachers. The Journal of Human Resource and Adult Learning, 3(2), 23-30.

Wei, C. (1997). Successful cooperation in EFL teaching: An investigation of DFLL learner's perceptions of Jigsaw cooperative learning technique in freshman English classes. Proceedings' of the fourteenth conference on English teaching and learning in the Republic of China (pp. 223-238). Taipei: Crane Publishing Ltd.

Widdowson, G. H. (1990). Aspects of language teaching. New York: Oxford University Press.

Wells, G. (1999). Dialogic inquiry: Towards a Sociocultural practice and theory of education. Cambridge: Cambridge University Press. http://dx.doi.org/10.1017/CBO9780511605895

\section{Copyrights}

Copyright for this article is retained by the author(s), with first publication rights granted to the journal.

This is an open-access article distributed under the terms and conditions of the Creative Commons Attribution license (http://creativecommons.org/licenses/by/4.0/). 